\title{
GELIAT ECOFEMINISME PEDESAAN DALAM PELESTARIAN LINGKUNGAN (Studi Kasus Di Desa Curug Muncar Pekalongan)
}

\author{
Shinta Dewi Rismawati, Irham Baihaqii Thoha, Supomo Ari Sasongko \\ IAIN Pekalongan \\ sinthadw@yahoo.com,irhambaihaqi72@gmail.com, paijo@yahoo.com
}

\section{ABSTRAK}

Keberadaan perempuan seringkali diabaikan dalam isu pelestarian lingkungan, padahal mereka memiliki peran strategis di dalamnya. Paper ini bertujuan untuk mengungkapkan alasan-alasan dilaksanakannya pemberdayaan perempuan dalam pelestarian lingkungan berikut model pendekatan yang dilakukannya untuk mendukung pemberdayaan perempuan di Desa Curug Muncar Pekalongan dalam pelestarian lingkungan. Penelitian kualitatif dengan partisipatory action research dipilih sebagai metode pendekatannya. Hasil dan analisisnya: pertama alasan-alasan sebagai dasar pembenaran dilaksanakannya kegiatan pemberdayaan perempuan adalah berpijak pada penjajagan kebutuhan yakni adanya kerentanan perempuan yang bersifat multidimensional (ekologi, psikologis, ekonomi dan sosial). Kedua model pendekatan yang digunakan untuk mendukung keberlanjutan pemberdayaan perempuan adalah dengan menerapkan tiga pilar pembangunan berkelanjutan yang mensinergikan dimensi ekologi, ekonomi dan sosial, ternyata mampu menyadarkan dan mengerakkan ecofeminism kelompok perempuan peduli dalam pelestarian lingkungan (P3L) di wilayah ini untuk peduli dalam pelestarian lingkungan.

$$
\begin{gathered}
\text { Kata Kunci:ecofeminism, participatory action research, } \\
\text { pembangunan berkelanjutan, program sak uwong } \\
\text { sak uwit }
\end{gathered}
$$




\section{ABSTRACT}

Environmental conservation issues always take the woman existence behind. Meanwhile, they have strategic contributions on it. This paper aims to reveal the approach and the reason for the implementation of women's empowerment in environmental conservation in order to support environmental conservation in Curug Muncar Pekalongan. The method of this research is qualitative and the approach method is participatory action research. The first reasons for justifying the implementation of women's empowerment activities are based on the need assessment of the multidimensional existence (ecological, psychological, economic and social) vulnerabilities. The second reason reveal that the sustainability of women's empowerment is by applying three pillars of sustainable. It synergize the ecological, economic and social dimension. It mobilize Kelompok Perempuan Peduli Dalam Pelestarian Lingkungan (P3L) in this region to care for environmental conservation.

Keywords:ecofeminism, participatory action research, sustainability development, sak uwong sak uwit programs.

\section{A. Pendahuluan}

Bencana tanah longsor yang menelan korban jiwa, seperti di Ponorogo, Bandung, Nganjuk dan beberapa wilayah di Indonesia lainnya telah menyadarkan bahwa kerusakan lingkungan yang berujung pada maraknya bencana alam tersebut terjadi bukan semata-mata masalah takdir (God made), tetapi sebagian besar adalah ulah manusia (man made). Manusia adalah penyebab utama dari kerusakan dan pencemaran lingkungan. Perilaku manusia dalam mengelola lingkungan pada tingkat lokal ikut menyumbang kondisi lingkungan di tingkat global (Keraf, 2002 : xiii). Kasus bencana akibat rusaknya lingkungan hidup sekarang ini, baik lingkup nasional maupun global sebagian besar bersumber pada perilaku manusia. Hal ini terjadi karena manusia dalam kehidupannya memiliki ketergantungan yang sangat erat dengan lingkungannya, sehingga keberadaannya sangat dipengaruhi dan mempengaruhi lingkungan sekitarnya baik yang bersifat biotik maupun abotik (Iskandar, 2009 : 1). Dari sudut ekologis, ada dua faktor mekanis yang menjadi penyebab bencana, yakni faktor kekacauan ekosistem yang disebabkan oleh ulah manusia (man-made disaster), diantaranya adalah kesalahan dalam pemanfaatan sumber daya alam (SDA) dan tata ruang, serta faktor perubahan 
iklim global (global climate change) yang diakibatkan banyaknya emisigas CO2 dan gas buangan lainnya, akibat industri, kendaraan berbahan bakar fosil dan lain sebagainya (Mangunjaya, 2006 : 190). Dengan kata lain, kerusakan lingkungan akibat perilaku destruktif manusia pada akhirnya kerusakan tersebut bisa memicu terjadinya bencana alam.

Bencana alam selalu berpotensi menimbulkan kerugian material dan menelan korban jiwa manusia. Korban bencana tersebut dapat menimpa siapa saja baik laki-laki maupun perempuan. Namun fakta di lapangan menunjukkan bahwa dominasi korban bencana alam adalah perempuan dan anak-anak. Perempuan adalah kelompok yang paling rentan dalam masyarakat dan paling menderita dari setiap degradasi lingkungan. Kondisi ini terjadi karena lingkungan baik secara langsung maupun tidak langsung merupakan landasan kehidupan perempuan (Jahan, 2008 : 5), sehingga merekalah yang paling menderita akibat degradasi lingkungan (Nasrin, 2012 : 149), oleh karena itu mereka sering disebut sebagai kelompok rentan dan tidak beruntung (vulnerable and disadvantage groups).

Pernyataan di atas menjadi benar, jika kita bercermin pada kasus bencana tsunami di Aceh, korban bencana alam secara kuantitas didominasi oleh perempuan dan anak-anak dibandingkan laki-laki. Banyaknya korban berjenis kelamin perempuan ini disebabkan pada saat bencana itu terjadi, mereka sedang berada di rumah karena pekerjaan domestik yang dilakukannya, melaksanakan tugas-tugas reproduksi lainnya, kapasistas serta akses untuk menyelamatkan dirinya sangat terbatas (Markhammah, 2013 : 1). Di Bangladesh, badai siklon telah menyebabkan kerusakan dan kematian hampir setiap tahun di negara ini. Siklon yang terjadi pada tahun 1970, 1988, 1991 dan 1998 menyebabkan hilangnya jutaan nyawa manusia, ternak dan kerusakan infra struktur yang parah. Dalam sebuah studi dari siklon 1991 terungkap bahwa akibat dari bencana badai tersebut, banyak perempuan yang mengalami malnutrisi, lemah dan rentan, gagal melindungi diri mereka. Sedangkan badai siklon yang terjadi tahun

1999

65 persen orang yang tewas adalah perempuan dan anak-anak (Ahmed, 1995: 68). Selama perubahan iklim ekstrem terjadi, maka perempuan dan anak-anak probalitas meninggal dunia ternyata lebih banyak hingga 85 persen dibandingkan laki-laki karena tingkat kerentanan mereka juga tinggi (Mirza, 2003 : 243). Pada saat terjadi gempa bumi 11 Juni 2015 di wilayah Dhading dan Rasuwa Nepal, pemerintah merilis data terdapat 5 persen kurban dari 8780 yang meninggal dunia adalah perempuan, sementara menurut UN Women korban 
tewas di Rasuwa, dari 251 korban, maka terungkap 62\% korban meninggal dunia dan 59 persen korban terluka dan itu adalah perempuan (Norlha, 2015 : 2).

Perempuan saat ini jumlahnya telah melebihi setengah dari jumlah penduduk dunia, akan tetapi keberadaannya selalu diabaikan dan terpinggirkan. Budaya patriarki telah menggeser kedaulatan perempuan dalam mengelola dan menentukan pangan, akibatnya perempuan telah menjadi terasing dan tercerabut dari komoslogi lingkungan hidupnya. Kondisi ini pada akhirnya menyebabkan perempuan ditinggalkan dalam proses pengambilan kebijakan, termasuk dalam proses pengambilan keputusan politik untuk dapat mengakses sumber-sumber kehidupannya. Padahal, perempuan menjadi garda terdepan dalam upaya pelestarian lingkungan. Sebagai kelompok dengan jumlah yang paling banyak, perempuan sesungguhnya memiliki banyak potensi untuk berkontribusi dalam kemajuan ekonomi, kemajuan sosial dan perlindungan lingkungan, akan tetapi keberadaannya justru dimarginalisasikan. Padahal akan lebih baik jika menggunakan populasi wanita di dunia untuk meningkatkan pertumbuhan ekonomi, mengurangi kemiskinan, meningkatkan kesejahteraan sosial, dan membantu memastikan pembangunan berkelanjutan di semua negara (OECD, 2008 :i), yang pro pada isu pelestarian lingkungan terjadi.

Isu pelestarian lingkungan sesungguhnya erat dengan peran perempuan. Perempuan merupakan figur yang sangat penting untuk menjamin pembangunan berkelanjutan. Perempuan merupakan aktor kunci dalam menggunakan, mengelola dan melindungi sumber daya alam (Haidar,1994 : 279). Perempuan memiliki peran yang sangat vital dalam pengelolaan dan pembangunan lingkungan. Partisipasi aktif dan dedikasi yang penuh merupakan hal yang paling ensensial dalam pembangunan berkelanjutan. Semua perempuan terutama mereka yang tinggal di daerah pedesaan ataupun daerah pegunungan biasanya memiliki hubungan khusus dengan lingkungan. Kehidupan mereka sangat bergantung dan berputar pada lingkungan hidup di mana dia hidup. Mereka sepenuhnya tergantung pada hutan untuk memenuhi kebutuhan sehari-hari seperti : air, pakan ternak, penyedian kayu bakar, hasil hutan sebagai sumber nuttrisi dll (Yadav, tt : 3). Di daerah pedesaan di Bangladesh, kehidupan seorang wanita sangat tergantung pada alam agar keluarganya tetap eksis melalui pengelolaan dan pengunaan bahan yang berasal dari sumber daya alami. Dalam sebuah keluarga, perempuan memiliki peran utama sebagai penyedia bahan makanan, pencari kayu sebagai bahan bakar dan pengumpul air untuk memasak, pemanas, minum dan mencuci (Haider, 1995 : 126), sehingga korban potensial dalam setiap kasus krisis lingkungan seperti 
deforestasi, pencemaran lingkungan, bencana banjir dan tanah longsor adalah perempuan. Hal tersebut juga dialami oleh perempuan di Desa Curug Muncar Kecamatan Petungkriyono Pekalongan yang potensial menjadi korban bencana alam termasuk tanah longsor.

Meskipun perempuan berpotensi besar sebagai korban akan tetapi disisi lain, perempuan juga memiliki peran yang besar dalam upaya perlindungan dan pencegahan pengrusakan lingkungan yang berpotensi menimbulkan bencana alam. Keterikatan dan ketergatungan warga dan perempuan terhadap lingkungan hidup disekitarnya juga terjadi di Kabupaten Pekalongan yang termasuk dalam wilayah rawan longsor dengan kategori menengah tinggi. Bencana tanah longsor sering melanda desa ini, meskipun belum jatuh korban jiwa dan sempat menjadikan Curug Muncar sebagai desa terisolir karena akses menuju desa tertutup (Radar Pekalongan, 2016). Berkaitan dengan isu keterkaitan dan keterlibatan perempuan terhadap isu-isu pencegahan kerusakan alam, maka permasalahan dalam paper ini adalah pertama mengapa kegiatan pemberdayaan perempuan pedesaan dalam pelestarian lingkungan di Desa Curug Muncar dilaksanakan? dan kedua strategi apa yang dilakukan untuk mendukung keberlangsungan pelaksanaan program pemberdayaan perempuan dalam pelestarian lingkungan di Desa Curug Muncar?. Tujuan paper ini adalah untuk mengkritisi alasan-alasan dilaksanakannya kegiatan pemberdayaan perempuan pedesaan dalam pelestarian lingkungan di desanya dan untuk mengidentifikasi model pendekatan yang digunakan untuk mendukung keberlangsungan pelaksanaan program tersebut.

Tema tulisan di atas, sesungguhnya menekankan pada penelitian yang berlanjut dengan aksi untuk menumbuhkan kesadaran kritis subjek dampingan dengan program pemberdayaan. Oleh karena itu, maka penelitian kualitatif yang dipadukan dengan partisipatory action research (PAR) dengan prinsip kegiatan dari, oleh dan untuk komunitas serta bentuk dan sifat kegiatan yang berakar pada mulai dari yang kecil-kecil, sederhana dan mulai dari sekarang (Afandi, 2013 : 47), digunakan sebagai metode pendekatannya. Pendekatan ini juga menekankan bahwa setiap proses kegiatan berlangsung mengikuti daur siklus program yang berkesinambungan yang dilakukan bersama antara fasilitator dan subjek dampingan.

Daur siklus program tersebut dimulai dari penjajagan serta identifikasi permasalahan, kebutuhan serta harapan subjek menjadi titik tolak dalam perencanaan, pelaksanaan serta evaluasi program pemberdayaannya untuk selanjutnya direfleksikan bersama. Dalam rangka pengayaan data, maka sumber 
data primer yang diperoleh dengan observasi, FGD, diskusi, wawancara mendalam kepada subjek dampingan dan informan lain, data itulah yang digunakan. Sumber data skunder yang berupa bahan pustaka diperoleh dengan studi dokumentasi.Triangulasi sumber data dan metode digunakan untuk mengecek keabsahan data. Teknik analisis data yang digunakan adalah model interaktif dengan berpijak pada penyajian data, reduksi data dan penarikan kesimpulan (Miles dan Huberman : 1992 : 104). Dengan pendekatan ini maka hasilnya tidak diperuntukkan untuk generalisasi, melainkan hanya berlaku pada konteks dan subjek di wilayah dampingan saja.

Berkaitan dengan tema di atas, maka hasil penelusuran bahan pustaka terdapat beberapa tulisan yang mengambarkan partisipasi untuk melestarikan, peduli dan berperilaku positif sesuai dengan wawasan kearifan dalam mengelola lingkungan sesungguhnya berakar dan melekat erat pada tradisi keibuan (Widjanarko, 2015 : 84), yang digerakkan oleh etika kepedulian dan semangat keibuan (Keraf, 2002 : 138). Keterkaitan dan keterlibatan perempuan secara nyata dan berhasil mendorong munculnya gerakan sosial untuk upaya pelestarian lingkungan, yang kemudian melahirkan prespektif alternatif dalam mengkritisi relasi hubungan antara manusia dengan alam sekitarnya yakni ecofminisme.

Meskipun konsep ecofemisme pertama kali lahir di daratan Eropa, tetapi dalam tataran praktis dan empiris, justru banyak dilakukan oleh perempuan di negara-negara berkembang bahkan di belahan dunia ketiga. Kondisi ini bukanlah sesuatu yang luar biasa, sebab bagi perempuan di wilayah ini, lingkungan hidup merupakan tempat mereka menggantungkan kehidupannya. Pada saat tempat bergantung kehidupannya ini dirampas serta dirusak atas nama pembangunan, modernisasi serta industrialisasi, maka perempuan di wilayah inilah bangkit untuk melawan tindakan destruktif tersebut. Perlawanan dan perjuangan mereka, itulah yang pada akhirnya ikut mengangkat populeritas gerakan ecofeminisme. Contohnya,Wangari Maathai dari Kenya yang memotori gerakan ecofeminise dengan fokus pada pemulihan lingkungan dengan memberdayakan perempuan miskin seiring dengan pertumbuhan ekonomi. Dia adalah pendiri gerakan green belt. Pada awalnya, gerakan green belt ini merupakan aktifitas menanam pohon saja dengan tidak menyentuh isuisu demokrasi dan perdamaian, namun akhirnya berkembang ke jalur publik yang lebih luas untuk membangun demokrasi. Maka, pohon pun menjadi simbol perjuangan demokrasi dan sebagai gerakan untuk melawan penyalahgunaan kekuasaan, korupsi, serta mismanajemen lingkungan hidup di Kenya (Meidina, 
2012 : 8). Selanjutnya gerakan yang dimotori oleh perempuan Chipko yang berada di perbukitan Garhwal di India barat, yang menentang perusahaan yang akan melakukan penebangan pohon dengan cara memeluk pohon (LPTP, 2010 : 211). Shiva menggambarkan wanita pedesaan miskin di Chipko sebagai "penukar lingkungan", mereka bertindak sebagai pemimpin dan aktivis. Mereka menempatkan hidup mereka pada kehidupan hutan yang berada di tanah mereka sendiri dan mereka menyatakan bahwa alam sangat diperlukan untuk bertahan hidup. Hutan sebagai penghasil tanah, air dan udara bersih (Shiva, 2005 :285).

Perempuan sebagai garda terdepan dalam pelestarian lingkungan di wilayah tersebut, maka Braidotti mengatakan bahwa keterlibatan yang kuat dari perempuan negara-negara berkembang maupun dunia ketiga dalam isu lingkungan disebabkan karena perempuan berposisi sebagai pihak yang terkena dampak langsung yang bersifat negatif serta merugikan akibat kerusakan lingkungan di daerahnya, oleh karena itu mereka akhirnya menempatkan isu lingkungan sebagai political point utama dalam gerakan sosialnya (Braidotti 1999:76).

Berpijak dari paparan diatas tentang keterkaitan dan keterlibatan perempuan dalam upaya pelestarian lingkungan, maka paper ini merupakan refleksi penelitian, oleh karena itu paper ini akan mengungkapkan alasan-alasan perlunya pelibatan perempuan pedesaan yang berada di Desa Curug Muncar dalam kegiatan pelestarian lingkungan dengan program sak uwong sak uwit yang telah menginspirasi warga untuk lebih peduli terhadap lingkungan, serta mendeskripsikan model pendekatan yang digunakan dalam mendukung keberlangsungan pelaksanaan pemberdayaan perempuan dalam pelestarian lingkungan di Curug Muncar.

\section{B. Pembahasan}

\section{Latar Belakang Pelibatan Perempuan Desa Sebagai Motor Pengerak Program Pelestarian Lingkungan}

Secara geografis Desa Curug Muncar berjarak 45 Km dari Ibu Kota Kajen Pekalongan dengan medan yang cukup sulit. Daerahnya relatif terpencil dan sulit dijangkau karena berada di lereng dan dataran pegunungan tinggi Dieng. Akibatnya hingga saat ini aliran lisrik dari PLN juga belum dapat diakses warga. Listrik yang dinikmati warga desa berasal dari pembangkit listrik tenaga 
mikrohidro (PLTMH) Curug Muncar dengan kapasistas $50 \mathrm{KW}$ yang awalnya dibangun secara swadana dan akhirnya mendapat bantuan APBN dan APBD pada tahun 2007 (Rismawati, 2011 : 237). Jumlah penduduk mencapai 480 orang, laki-laki 246 dan perempuan 243. Jumlah kepala keluarga mencapai $135 \mathrm{KK}$. Mata pencarian utama didominasi sebagai petani serta buruh tani yang mencapai 318. Pendidikan warga mayoritas adalah pendidikan dasar yaitu sebanyak 250, SLTP 45, SLTA 3, Akademik 6 dan sarjana 3 orang. Di desa ini hanya terdapat 1 SD dan 1 PAUD/TK yang letaknya berdekatan dengan kantor kelurahan. Rendahnya tingkat pendidikan masyarakat disebabkan akses untuk menjangkau sekolah tingkat pertama-menengah dan tingkat atas relative jauh, hanya ada di ibu kota kecamatan dan kabupaten yang relatif jauh. Agama Islam adalah agama mayoritas yang dianut oleh warga desa. Di desa ini ada 1 masjid dan 2 mushola sebagai sarana warga untuk melakukan ritual ibadah sehari-hari (Rismawati, 2011 : 238).

Kehidupan sosial kemasyarakatan warga sangat akrab dalam arti mereka cukup mengenal satu dengan lain secara baik, hal ini disebabkan karena mereka hidup secara berkelompok, sehingga pemukiman warga terpusat pada dua titik yakni Dusun Watu Gajah dan Dusun Curug Muncar. Meskipun desa ini letaknya terpencil, akan tetapi potensi sumber daya alamnya cukup menjanjikan untuk dikembangkan, sehingga dapat membantu menggerakkan ekonomi masyarakatnya yakni dengan basis ekowisatanya. Potensi eko wisata menjadi harapan karena di desa ini terdapat hutan milik perhutani, hutan perawan, hutan rakyat, air terjun (Curug Ceret Kembar) dengan sumber daya air yang melimpah, lahan pertanian dengan sistem terasering yang eksotik dan udara yang sejuk. Hasil pertanian yang menonjol adalah padi, singkong dan jagung. Hasil perkebunan rakyat antara lain adalah pisang, sengon, nangka, kopi, kelapa, mangga, rambutan dan aren, sementara hutan perhutani ditanami pinus.

Tulisan pada sub bahasan pertama ini difokus pada penggalian alasanalasan pembenar untuk melibatkan perempuan agar lebih peduli dan konsen terhadap isu pelestarian lingkungan dalam rangka pencegahan bahaya tanah longsor di desanya. Sehingga riset ini pada akhirnya akan mengambarkan upaya untuk menumbuhkan kesadaran kritis perempuan sebagai agen perubahan sosial. Kesadaran kritis yang dibangun disini antara lain menyadarkan bahwa kelangsungan kehidupan warga sangat tergatung pada tempat dimana mereka tinggal, jika alam rusak, maka rusak pula kehidupan warga baik dari sisi ekonomi, sosial maupun budaya. Berpijak dari misi tersebut, maka PAR digunakan sebagai bagian dari riset bersama. Secara sederhana PAR dapat 
dipahami sebagai kegiatan yang integratif yang menggabungkan penelitian sosial, kegiatan pendidikan, penyadaran, pelatihan dan sekaligus aksi sosial (Syafaat, 2006 : 90). Kegiatan yang memadukan lima elemen dasar dari PAR inilah yang dilakukan untuk mendapatkan berbagai alasan pembenaran dilakukannya kegiatan pemberdayaan perempuan dalam mencegah krisis lingkungan di wilayah Curug Muncar.

Krisis lingkungan merupakan ancaman laten terhadap keberlangsungan hidup warga yang tinggal di daerah rawan longsor. Perempuan dapat dijadikan agent of change sekaligus leader dalam penyelesaian persoalan lingkungan dengan jalan merubah cara pandang serta perilaku mereka terhadap alam serta lingkungannya. Arne Naess mengatakan bahwa krisis lingkungan dewasa ini hanya bisa diatasi dengan melakukan perubahan cara pandang dan perilaku manusia terhadap alam secara fundamental dan radikal, yang dibutuhkan adalah sebuah pola hidup baru yang tidak hanya menyangkut orang per orang tetapi juga budaya masyarakat secara keseluruhan. Artinya dibutuhkan etika lingkungan hidup yang menuntun manusia untuk berinteraksi secara baru dengan alam semesta (Keraf, 2002 : xiv), dan perempuan memiliki potensi tersebut. Pola hidup baru disebut sebagai ecosophy yakni gerakan kearifan merawat bumi sebagai sebuah rumah tangga yang nyaman bagi semua kehidupan. Gerakan ini diharapkan mampu menjadi budaya baru yang bisa dimulai, dipertahankan, diajarkan dan diwariskan dari satu orang ke orang lain (Keraf, 2002 : xxi). Dengan demikian gerakan ini beroreintasi pada mendorong tumbuhnya kesadaran yang akan merubah cara pandang subjek terhadap alam dan lingkungan hidup.

Salah satu upaya untuk meningkatkan kesadaran, perubahan cara pandang dan kepedulian mereka terhadap lingkungan adalah melalui program pemberdayaan perempuan. OSAGI mengatakan

women's empowerment means women gaining more power and control over their own lives. This entails the idea of women's continued disadvantage compared to men which is apparent in different economic, socio-cultural and political spheres. Therefore, women's empowerment can also be seen as an important process in reaching gender equality, which is understood to mean that the "rights, responsibilities and opportunities of individuals will not depend on whether they are born male or female (OSAGI, $2001: 2$ ).

Pemberdayaan perempuan dapat digunakan sebagai pintu masuk untuk menyelesaikan persoalan lingkungan hidup yang dihadapi dengan pendekatan multidispliner yakni pendekatan ekologi, kultural, ekonomi maupun sosial. 
Keraf sendiri mengingatkan bahwa persoalan lingkungan hidup harus didekati secara lebih komprehensif-holistik termasuk moral karena persoalan tersebut tidak hanya berkutat pada teknis parsial belaka (Keraf, 2002 : ix). Dalam rangka menggali alasan-alasan kegiatan pemberdayaan perempuan untuk peduli pada pecegahan bencana longsor, tim peneliti mau tidak mau dituntut untuk membaur dengan mereka, agar bisa memahami cara pandang dan cara mereka menjalani kehidupan sehari-hari. Sebagai langkah awal maka, pertemuan rutin antara tim peneliti dengan kelompok perempuan yang berjumlah 20 perempuan dilaksanakan di rumah Bapak Mudji (mantan kepala desa). Tempat ini kemudian dijadikan sebagai posko bersama. Pemilihan kelompok perempuan sebagai subjek dampingan terutama didasarkan bahwa perempuan dinilai punya potensi dalam pelestarian lingkungan tetapi keberadaannya masih diabaikan, perempuan di wilayah ini belum banyak diberdayakan dalam berbagai program kegiatan, perempuan lebih banyak tinggal dirumah dibandingkan laki-laki yang berstatus sebagai kepala rumah tangga dan belum banyak kegiatan ekonomi kreatif berbasis potensi lokal yang diinisasi dan dikelola oleh perempuan.

Dari hasil pertemuan rutin dan intens dengan subjek dampingan, maka terungkap berbagai permasalahan, harapan dan solusi yang menjadi agenda bersama antara tim peneliti dan subjek dampingan, maka teridentifikasi alasanalasan yang menjadi dasar perlunya kegiatan pemberdayaan perempuan dalam pencegahan bencana tanah longsor, antara lain ada empat kerentanan yakni :

\section{a. Adanya kerentanan ekologi dengan level cukup tinggi}

Hal ini terbukti frekuensi bencana tanah longsor ketika musim hujan cukup tinggi, sumber daya air yang sebelumnya melimpah, saat ini jika terjadi musim kemarau menyebabkan debit air menurun sehingga listrik yang diproduksi mikrohidro Curug Mundar tidak stabil dan warga mulai kesulitan mencari air bersih untuk kebutuhan sehari-hari, kayu bakar sulit dicari karena meningkat kebutuhan warga sebagai bahan bakar untuk memasak sebab gas elpiji sulit didapatkan karena harganya mahal, sementara itu perilaku deforestisasi warga karena tuntutan ekonomi juga meningkat, demikian pula banyak warga yang melakukan alih fungsi hutan untuk ladang maupun pemukiman warga, suhu antara siang dan malam cukup esktrim padahal sebelumnya tidak pernah terjadi. Kerentanan ekologi ini terjadi akibat terjadinya deforestasi yang cukup memprihatinkan. Akibat dari deforestisasi tersebut, maka kondisi ini mengharuskan perempuan untuk menghabiskan lebih banyak waktu untuk mengumpulkan kayu bakar. 
Kondisi ini persis yang dialami oleh perempuan di Bangladesh. Di Bangladesh, perempuan harus menghabiskan lima jam dalam sehari untuk mengumpulkan kayu bakar. Selain itu, wanita menggunakan limbah industri, kertas dan plastik sebagai bahan bakar padahal bahan ini yang menciptakan polusi udara di perkotaan. Perempuan dan anak-anak sangat terpengaruh oleh polusi udara (Haider, 1995 : 126). Singkat cerita, krisis lingkungan menyebabkan perempuan lebih berpotensi sebagai korban. Namun menjelaskan bahwa sebagai manajer rumah tangga, perempuan yang pertama menderita, terutama ketika mata pencaharian yang berkelanjutan tidak seimbang, ketika air menjadi tidak portabel, toko-toko makanan habis, pohon-pohon menghilang, tanah menjadi tidak bisa dipertahankan dan perubahan iklim. Hal ini menjadikan perempuan mengurangi jatah makan. Akibatnya sekitar $70 \%$ wanita dan anak-anak menderita kekurangan gizi dan $30 \%$ menderita defisit kalori (misalnya hamil dan wanita menyusui). Mereka sering berjalan lebih jauh dan bekerja lebih keras untuk memastikan kelangsungan hidup keluarga mereka (Najmun, 2008 23:).

\section{b. Adanya kerentanan psikologis warga terutama perempuan dan anak- anak.}

Kerentanan psikologis ini ditandai dengan munculnya rasa cemas dan ketakutan yang cukup tinggi terutama jika musim hujan tiba. Mayoritas perempuan di desa ini rata-rata merasa kuatir terutama jika musim hujan tiba. Ketakutan terjadi bencana tanah longsor kian menguat di kalangan perempuan khususnya dan warga pada umumnya, karena frekuensinya makin sering terjadi akibat deforestisasi hutan, tidak saja di malam hari tetapi juga siang hari. Bencana tanah longsor yang terjadi di desa sudah menelan korban yakni empat ternak sapi mati tertimbun, bendungan mikrohidro yang jebol, balai desa rusak dan ladang dan sawah yang gagal panen karena rusak tertimpa tanah longsor. Mereka merasa kehidupannya tidak aman, karena bencana dapat terjadi sewaktu-waktu, selanjutnya dari aspek psikologis, perempuan juga merasa cukup tertekan (stress) dengan terbatasnya pendapatan suami yang banyak tergantung dari hasil pertanian dan perkebunan, sementara harga kebutuhan sehari-hari meningkat. Karena kondisi ini seringkali istri dan anak jadi korban sasaran kemarahan maupun omelan suami, demikian pula sebaliknya suami juga sering menjadi sasaran kemarahan istri, sehingga terkadang muncul pertengkaran bahkan perceraian karena persoalan ekonomi rumah tangga. 


\section{c. Adanya kerentanan ekonomi keluarga.}

Kerentanan ekonomi keluarga terjadi karena mayoritas pekerjaan warga adalah petani dan buruh. Kehidupan dan pendapatan mereka bersifat musiman karena banyak menggantungkan kehidupannya dari hasil pertanian serta perkebunan. Padahal saat ini kondisi panen tidak menentu, akibatnya pendapatan keluarga menurun. Menurunnya pendapat warga dipicu oleh menurunnya kualitas hasil pertanian dan perkebunan akibat serangan hama dan perubahan iklim global, sementara istri hanya berkutat dengan tugas domestik dan reproduksi dan sesekali membantu suami di sawah maupun di ladang jika kebutuhan tambahan tenaga diperlukan, kalaupun di bayar upahnya relatif lebih sedikit dibanding laki-laki. Pendapatan yang mereka peroleh makin terasa kecil jika dibandingkan dengan harga-harga kebutuhan pokok keluarga yang terus meningkat.

\section{d. Adanya kerentanan sosial}

Kerentanan sosial ini dipicu oleh munculnya sikap individualism diantara warga, lunturnya rasa kebersamaan serta gotong royong dalam mengatasi persoalan sosial kemasyarakatan maupun lingkungan. Warga kadang merasa tidak peduli dengan kondisi warga yang terkena musibah karena bencana tanah longsor sebab hal itu takdir hidup korban, seringkali mereka berpikir yang penting bukan keluarganya yang menjadi korban. Selain itu juga meningkatnya konsumerisme seiring dengan adanya listrik yang dinikmati warga seperti persaingan dalam pemilikan benda elektronik dan motor yang merujuk simbol sebagai orang kaya di desa.

Berbagai kerentanan yang dikeluhkan subjek dampingan ini sesungguhnya menyiratkan bahwa mereka sadar kehidupan dalam keadaan terancam dan mereka berpeluang besar menjadi korban bencana tanah longsor.Yuliana yang mengatakan bahwa di pedesaan, perempuan adalah pengerak perekonomian juga pertanian. Sebagian besar perempuan bergelut di ladang serta sawah dengan tanaman, air, tanah dan hutan. Minimnya pengetahuan perempuan tentang dampak lingkungan bagi kesehatan reproduksi. Kesehatan dan hak reproduksi dan seksual menjadikan perempuan sebagai korban pencemaran lingkungan yang diakibatkan oleh kebijakan pembangunan yang tidak pro life terhadap perempuan dan lingkungan (Yuliana, 2015 :62).

Disamping muncul kesadaran bahwa mereka adalah korban yang potensial, mereka juga menyadari bahwa berbagai kerentanan tersebut bermuara pada fenomena rusaknya hutan (deforestisasi) dan rusaknya 
lingkungan (degredasi lingkungan), sehingga akhirnya terjadinya perubahan iklim yang ekstrim. Dengan kata lain, mereka menyadari bahwa persoalan degredasi serta deforestisasi (kerentanan ekologi) telah menjadi penyebab utama munculnya kerentanan ekonomi, sosial dan psikologis. Oleh karena itu, keinginan mereka mencari solusi untuk mengatasi keempat kerentanan yang mereka alami itulah yang menjadi dasar dilaksanakannya program pemberdayaan perempuan dalam pelestarian lingkungan di Curug Muncar. Kelompok perempuan ini kemudian dideklarasikan diri sebagai perempuan peduli pelestarian lingkungan (P3L) Curug Muncar, yang beranggotakan 20 orang.

\section{Penerapan Tiga Dimensi Pembangunan Berkelanjutan Sebagai Model Pendekatan}

Isu-isu kemasyarakatan seperti pendidikan, kesehatan, air bersih dan sanitasi yang termaktub pada tujuan Pembangunan Milenium (MDGs) juga dekat dengan kehidupan perempuan. Kehidupan perempuan dalam semua aspek yang melingkupinya senantiasa menjadi spektrum yang menarik di kaji, termasuk dalam isu pelestarian lingkungan hidup. Meskipun perempuan memiliki pengetahuan dan pengalaman dalam menjaga dan merawat alam, akan tetapi keberadaannya senantiasa terpinggirkan baik secara kultur maupun struktur.

Peran perempuan sebagai actor, leader dan decision makers dalam pelestarian lingkungan seringkali tidak mendapat perhatian. Potensi perempuan yang besar dapat dikembangkan dalam pemeliharaan, pelestarian lingkungan dan pencegahan pencemaran lingkungan. Selain jumlah perempuan cukup mendominasi, juga terdapat bukti bahwa perempuan mampu mengatasi masalah lingkungan disekitarnya seperti yang telah dikemukakan pada paparan sebelumnya. Selama ini perempuan kurang diikutsertakan dalam pengelolaan lingkungan baik itu dalam akses, partisipasi, kontrol dan manfaat. Perempuan juga kurang diberi pengetahuan tentang cara melestarikan lingkungan.

Berpijak dari persoalan di atas, maka peningkatan pengetahuan, kesadaran dan ketrampilan perempuan dalam mengelola dan melestarikan alam dan lingkungan hidup di sekitarnya menjadi keniscayaan. Pemberdayaan perempuan dalam kegiatan pelestarian lingkungan dengan melakukan konservasi alam menjadi program yang mutlak dilakukan secara sistematis, komprehensif dan berkelanjutan. Dalam rangka mencari pembenaran atas kegiatan pemberdayaan ini, maka terlebih dahulu dilakukan penjajagan 
kebutuhan bersama sebagaimana telah dipaparkan dalam sub bahasan sebelumnya. Hasil pemetaan penjajagan kebutuhan bersama tersebut, maka terdapat empat kerentanan (ekologi, ekonomi, psikologis dan sosial) yang tergambar dalam pohon masalah tersebut kemudian ditindaklanjuti dengan penyusunan program untuk menjawab permasalahan dengan membuat pohon harapan. Dari berbagai persoalan tersebut, maka matrik rangking penyelesaian masalah mengacu pada konsep pembangunan berkelanjutan sebagai model pendekatan pemberdayaan perempuan. Alasan pengunaan konsep ini sesungguhnya sederhana, yakni berbagai permasalahan yang dikemukakan oleh subjek dampingan ternyata menyiratkan dimensi ekologi, ekonomi dan sosial sekaligus dan ketiga dimensi tersebut saling berkaitan.

Model pendekatan yang digunakan dalam program mengacu pada pola pembangunan berkelanjutan yakni berpijak pada tiga pilar yakni dimensi ekologi, ekonomi dan sosial (Mulyadi, 2015 : 35). Pembangunan berkelanjutan adalah model pembanguan yang menekankan pada tiga aspek yakni ekonomi, ekonomi dan sosial dengan aspek ekologi dan ekuitas sosial sebagai aspek utama. Penekanannya tidak semata-mata pada dimensi pertumbuhan ekonomi tetapi lebih pada perbaikan kualitas kesejahteraan sosial dan perkembangan potensial manusia. Proteksi lingkungan alam tidak dimaksudkan untuk mempeti-es-kan ekosistem dan tidak boleh berubah melalui evolusi dan proses-proses ekologi tetapi lebih menekankan pada menjaga perbuahan-perubahan tersebut agar tidak menyebabkan krisis lingkungan (Iskandar, 2009 : 41). Model pendekatan ini dilakukan, sebab tim dan subjek dampingan menyadari bahwa keberlanjutan ekologi memegang peranan penting dalam kehidupan manusia karena aspek ekologi menjadi bagian vital dalam menunjang pembangunan ekonomi dan sosial. Dengan demikian ketiga dimensi dalam pembangunan berkelanjutan perlu diaplikasikan dalam program. Jika model pendekatan ini dilakukan secara serius dan berkelanjutan, maka keempat kerentanan yang menjadi keluhan bersama lambat laun akan teratasi.

Model pendekatan pembangunan berkelanjutan ini sesungguhnya selaras dengan ide pembangunan kesejahteraan sosial (social welfare development) yang menjadi masalah utama bagi sebagian besar hidup warga terutama di pedesaan. Pembangunan kesejahteraan sosial ini bertujuan untuk meningkatkan kualitas hidup masyarakat melalui peningkatan modal ekonomi (economic capital), manusia (human capital), kemasyarakatan (society capital-modal capital) dan perlindungan (security capital) secara terintegrasi dan berkesinambungan (Suharto, 2005 : viii). Peningkatan modal ekonomi merujuk pada tumbuhnya 
mata pencarian (livehood) masyarakat yang memungkinkan mereka mampu memperoleh dan mengelola aset-aset finansial dan material untuk memenuhi kebutuhan dasarnya sesuai dengan standar kemanusiaan yang layak dan berkelanjutan. peningkatan modal manusia menekan pada aspek berkembangnya kemampuan atau kapasitas intelektual, emosional dan spiritual manusia yang memungkinkan mereka mampu menjalankan peran-peran secara konsisten dalam kehidupannya. Peningkatan modal kemasyarakatan merujuk pada tumbuh dan menyebarnya kepercayaan di antara elemen masyarakat, dan peningkatan modal perlindungan menekankan pada adanya jaminan keamanan dan keterjaminan (Suharto, 2005 : viii), baik dalam ranah kehidupan manusia baik secara pribadi, sosial, maupun sebagai bagian dari kehidupan alam semesta.

Ketiga pilar dalam pembangunan berkelanjutan tersebut dipilih sebagai model pendekatan kegiatan pemberdayaan perempuan, sebab kegiatan ini diarahkan pada misi bersama yakni peningkatan pelestarian lingkungan, dengan mengkaitkan dengan masalah peningkatan ekonomi keluarga sekaligus meminimalisir krisis sosial karena kurangnya kesadaran dan kepedulian bersama tentang alam. Isu bersama yang menguat adalah terjadinya degredasi lingkungan. Masalah bersama ini kemudian di break-down dalam berbagai fokus baik dari perspketif ekologi, ekonomi maupun sosial. Program yang hendak diwujudkan diarahkan pada program untuk mendukung reforestisasi (reboisasi) berbasis komunitas. Dari sinilah lahir program unggulan yakni program sak uwong sak uwit (SUSU). Program ini mengharuskan setiap anggota untuk menanam satu pohon di lahan milik sendiri, baik di sekitar rumah, kebun, maupun ladang dengan jumlah pohon minimal sama dengan jumlah anggota keluarga di setiap jengkal tanah yang dimilikinya baik dari sendiri, iuran swadana hasil dari usaha bersama maupun bantuan dari pihak lain.

Mereka sepakat untuk menanam tanaman yang dapat mendatangkan nilai ekonomi ataupun tanaman keras lain yang dapat menahan erosi tanah. Pada awal program kegiatan, pohon yang bernilai ekonomis (buah-buahan) dipilih sebagai modal perjuangan bersama untuk pelestarian lingkungan dengan asumsi bahwa selain membantu proses reboisasi lahan kritis juga dapat meningkatkan pendapatan baik dalam jangka pendek maupun jangka panjang. Awalnya kegiatan ini dipandang sebagai kegiatan kelompok ibu-ibu yang kurang memiliki daya ungkit bagi pelestarian lingkungan dan juga peningkatan ekonomi keluarga. Suka dan duka sudah dilalui bersama oleh kelompok perempuan yang tergabung dalam P3L Curug Muncar, sehingga akhirnya rintisan program tersebut akhirnya eksis dan berkelanjutan. Keberadaan 
kelompok P3L Curug Muncar ini akhirnya membawa manfaat bagi anggota maupun warga, dalam mengerakan ekonomi produktif dan meramaikan eko wisata di desanya.

Memang terlalu dini untuk mengatakan bahwa program ini telah sukses dan membawa perubahan besar bagi warga, karena masih perlu dievalusi dan dilihat dampak dari kegiatan ini di masa mendatang. Meskipun demikian, tetap saja apa yang telah dirintis oleh P3L Curug Muncar dapat dikatakan sebuah prestasi yang dilakukan oleh perempuan pedesaan dengan segala keterbatasan sumber daya yang dimiliki, tetapi muncul kesadaran dan kepedulian secara pribadi maupun kolektif untuk peduli dengan isu pelestarian lingkungan meskipun lingkupnya masih kecil. Program SUSU yang digagas oleh kelompok P3L Curug Muncar ini, memang hampir mirip dengan apa yang dilakukan oleh Professor Wangari Maathai (sang penerima Nobel) dari Kenya yang memotori dan memberdayakan perempuan miskin dengan aktifitas menanam 1000 pohon dengan gerakan green belt-nya (Meidina, $2012: 8$ ). Tujuan gerakan ini adalah untuk mengatasi krisis kayu sebagai bahan bakar di daerah pedesaan, sekaligus mencegah penggundulan dan bahaya erosi tanah. Gerakan tersebut mengurangi dampak deforestasi dan menyediakan forum bagi perempuan untuk menjadi pemimpin yang kreatif dan efektif (Salman, 2007 :859).

Persamaannya kedua gerakan ini antara lain : pertama gerakan ini dilakukan oleh perempuan pedesaan yang mayoritas tidak berpendidikan tinggi dan miskin; kedua mereka sama-sama memiliki keterkaitan erat dengan lingkungan dimana mereka bertempat tinggal, ketiga mereka sama-sama menyadari sebagai korban potensial dalam kasus krisis dan bencana alam, keempat mereka sama-sama menggunakan pohon sebagai pintu masuk gerakan sosial dan pemberdayaan masyarakat dengan meletakan isu pelestarian lingkungan sebagai isu sentralnya, dan kelima mereka sama-sama melibatkan akademis dalam kegiatannya.

Sementara perbedaannya terlihat dalam empat hal. Pertama, asal usul gerakan penyadaran dan pemberdayaannya berbeda, P3L Curug Muncar karena ada intervensi dari pihak lain (tim peneliti) sementara gerakan green belt murni dari masyarakat yang dimotori oleh Wangari Maathai. Kedua, gerakan P3L Curug Muncar selain menggunakan pohon, mereka juga memiliki kebun pisang milik bersama dan warung bersama sebagai media untuk mendukung keberlangsungan program, sementara gerakan green belt hanya berkutat dengan penanaman pohon saja. Ketiga, gerakan P3L Curug Muncar masih dalam lingkup kecil dan lokal, sementara gerakan green belt sudah menjangkung 
lingkup nasional dan internasionaL. Keempat gerakan P3L Curug Muncar belum mampu mempengaruhi ranah politik dan pengambil kebijakan di level atas, sementara gerakan green belt justru sebaliknya. Dengan demikian apa yang dilakukan oleh P3L Curug Muncar adalah wujud nyata dari ecofeminism yang digerakkan oleh perempuan di pedesaan.

Ide ecofeminism pertama kali dilontarkan oleh Francoise d'Eaubonne pada tahun 1974 dalam bukunya yang berjudul Le Feminisme ou La Mort, tulisannya mampu mengunggah kesadaran manusia khususnya perempuan untuk melakukan sebuah revolusi ekologis dalam penyelamatan lingkungan (Amstrong dan Botzler, 1993 : 430). Fox mengatakan bahwa gerakan ecofeminisme ini tidak sekedar melawan antroposentrisme yakni etika lingkungan yang berpusat pada manusia (human-centered environmental ethics) tetapi juga androsentrisme yakni etika lingkungan yang berpusat pada laki-laki (male-centered enviromental ethics). Dalam arti itu, ecofeminism juga mengkritik ecosentrisme yakni etika lingkungan yang berpusat pada lingkungan, khususnya deep ecology-nya karena dianggap masih berkiblat pada antroposentris yang ujung-ujungnya bersumber pada dominasi laki-laki atas alam sebagai penyebab krisis eologi (Sessions, 1995 : 272). Karen J. Warren mengatakan bahwa akar dari seluruh persoalan krisis lingkungan sesungguhnya dipicu oleh pengkultusan secara berlebihan tentang logika dominasi yang cenderung membenarkan subordinasi, nuansa hierarkhi dan adanya dualisme nilai yang berujung pada kerangka konsep yang menindas dan eksploitatif (Amstrong dan Botzler, 1993 : 435), baik oleh manusia terhadap alam maupun manusia terhadap manusia yang lain (laki-laki terhadap perempuan).

Eksistensi dan keberlanjutan program ini tidak terlepas dari munculnya kesadaran bersama untuk secara swadaya dan sukarela menyukseskan tujuan bersama. Bentuk keswadayaan dan kesukarelaan tersebut dibuktikan adanya lahan yang tidak produktif milik salah satu anggota yang direlakan untuk jadi lahan produktif bersama selama tiga tahun. Lahan tersebut ditanami aneka pohon pisang yang memiliki nilai jual tinggi, seperti pisang jenis kapok tanjung, raja nangka, ambon, gebyar dll. Dalam hitungan kurang lebih enam bulan usaha ini berhasil dengan panen raya. Hasil panen tersebut ada yang dijual untuk tambahan modal beli bibit dan biaya perawatannya, sebagian lainnya dijadikan aneka pangan berbasis pohon pisang baik untuk konsumsi sendiri maupun dijual ke pasar.

Aneka makanan berbasis pohon pisang antara lain : keripik pisang, sale pisang aneka rasa, dendeng jantung pisang, kerupuk bonggol pisang, aneka cake 
pisang. Peluang usaha penjualan hasil pisang ini cukup mengembirakan seiring dengan makin terkenalnya ekowisata di daerah ini. Mereka bahkan membangun warung aneka oleh-oleh olahan potensi lokal kepada wisatawan yang hasilnya diputar sebagian untuk usaha dan sebagian untuk beli bibit tanaman (dimensi ekonomi). Dari modal lahan pohon pisang bersama inilah program sak uwong sak wit makin eksis dan mendapatkan perhatian dari warga sekitar termasuk pemerintahan desa (dimensi ekologi).

Dalam rangka menyebarkan program SUSU tersebut, awalnya tim bersama kelompok perempuan mengusahakan sendiri bibit dari potensi yang ada di desa dari iuran bersama. Setelah panen raya maka tambahan pembelian bibit diperoleh dari hasil penjualan hasil panen kebun pisang, dari warung, juga dari hasil pengajuan permohonan bantuan bibit tanaman pada Dinas Perumahan Rakyat dan Kawasan Pemukiman dan Lingkungan Hidup Kabupaten Pekalongan. Hasil bibit pohon yang terkumpul di awal program kurang lebih 125 pohon dan dibagikan kepada semua anggota.Merekapun secara bahumembahu menanam tamanan di sekitar rumah dan pekarangan milik mereka. Seiring dengan keberhasilan program pengolahan kebun pisang bersama dan program SUSU, maka sekarang pembagian bibit juga diperluas kepada warga masyarakat. Saat ini, pelan namun pasti kesadaran perempuan dan warga untuk peduli dengan lingkungan dan terlibat aktif dalam pencegahan bencana longsor menjadi kian nyata. Kebersamaan dan kegotong-royongan yang selama ini sudah mulai luntur di desa ini, maka dengan keberadaan dan aksi dari P3L Curug Muncar menjadi hidup kembali (dimensi sosial).

Paparan di atas, menunjukkan bahwa perempuan yang tergabung dalam P3L Curug Muncar ini memang belum familiar dengan konsep pembangunan berkelanjutan, akan tetapi kegiatan yang mereka lakukan sesungguhnya merupakan implementasi konsep pembangunan berkelanjutan secara nyata. Berpijak pada realitas maka P3L Curug Muncar telah mengapreasi dan mengimplementasi 3 pilar pembangunan sekaligus yakni dimensi ekologi dengan program SUSU, dimensi ekonomi dengan adanya peningkatan ekonomi keluarga dan dimensi sosial dengan menguatkan kembali rasa kebersamaan, keswadayaan, kerelaan dan gotong royong dalam masyarakat.

Kegiatan yang dilakukan perempuan di wilayah ini relatif berhasil, karena modal sosial yang dimiliki oleh mereka. Modal sosial adalah satu komponen penting dalam menggerakkan kebersamaan, mobilitas ide, adanya saling percaya, nilai-nilai yag dijunjung bersama dan adanya relasi timbal balik yang saling menguntungkan untuk mencapai tujuan bersama (Hasbullah, 2006 : 18). 
Modal sosial yang dimiliki kelompok P3L Curug Muncar inilah yang pada akhirnya mampu mewujudkan mimpi, harapan dan tujuan bersama yakni teratasinya semua kerentanan ekologi, kerentaan ekonomi, kerentanan psikologis dan kerentanan sosial akibat kerusakan hutan dan lingkungan di mana mereka tinggal.

Berpijak pada program SUSU, maka sekecil apapun peran perempuan dalam upaya menjaga dan merawat lingkungan disekitarnya patut kita apresiasi, sebab terjaganya pohon dan hutan, merupakan pertanda awal terjaga dan terjaminnya kehidupan manusia, sebab hutan yang lestari akan menjamin keberlangsungan lahan yang subur, sumber daya air dan oksigen yang bersih sebagai elemen dasar kehidupan manusia. Program SUSU yang dilakukan oleh P3L Curug Muncar adalah wujud partisipasi perempuan yang diamanatkan oleh UU Perlindungan dan Pelestarian Lingkungan Hidup. Sebagai bagian dari warga negara serta masyarakat, maka partisipasi P3L Curug Muncar dalam gerakan menanam pohon di desanya dianggap memiliki peran besar dalam mengembalikan degradasi hutan dan kerusakan lingkungan, meskipun levelnya baru lingkup kecil.

Laporan Kementrian Kehutanan sebagai pilot project memberikan "klaim" terhadap gerakan tanam yang dilakukan perempuan sebagai gerakan berdampak positif karena telah berhasil menjadikan degradasi hutan menurun dari 2,83 juta hektar pertahun menjadi 1,08 juta hektar (data per Agustus 2008) atau menurun sampai angka $60 \%$. Penurunan tersebut sangat cepat sebab pada tahun 2005, Indonesia memiliki lahan kritis dari kerusakan 59, 2 juta hektar per tahuan dan pada tahun 2006 menurun menjadi 30 juta hektar. Prestasi tersebut diraih setelah pemerintah melakukan gerakan hijau dengan menjadikan perempuan sebagai penggerak selama kurun waktu 2004-2007. Partisipasi perempuan dalam gerakan menanam pohon yang dikoordinasikan oleh Kementrian Kehutanan RI bersama Kementrian Pemberdayaan Perempuan RI mewujud dalam berbagai kegiatan yang terpolakan dalam program antara lain "Gerakan Rehabilitasi Hutan dan Lahan (Gerhan), Indonesia Menanam dengan semboyan "Kecil Menanam, Besar Memanen", "Tebang Satu Tanam Seribu", serta "Santri Menanam, Kyai Memanen, Anak dan Cucu Memanen", "Duta Tanam Sekolah" (Jurnal Pena, edisi 2, 2005). Gerakan menanam pohon di Indonesia yang awal mulanya hanya memiliki target 10 juta pohon, namun antusiasme masyarakat dalam berpartisipasi yang sangat tinggi membuat pencapaian target tersebut meningkat 14, 1 juta pohon (Kementerian Kehutanan RI, $2008: 3)$. 
Peran secara nyata perempuan sebagaimana disebutkan di atas untuk upaya pelestarian lingkungan sesungguhnya merupakan amanat Pasal 70 UU No. 32 Tahun 2009 tentang Perlindungan dan Pengelolaan Lingkungan Hidup ( UU PPLH). Peran perempuan dalam lingkungan hidup dapat ditunjukan tersirat di dalam Pasal 70 tentang peran masyarakat, yang menyebutkan bahwa: 1). Masyarakat memiliki hak dan kesempatan pemikiran yang sama dan seluasluasnya untuk berperan aktif dalam perlindungan dan pengelolaan lingkungan hidup. 2). Peran masyarakat dapat berupa: a. pengawasan sosial; b. pemberian saran, pendapat, usul, keberatan, pengaduan; dan/atau c. penyampaian informasi dan/atau laporan. 3). Peran masyarakat dilakukan untuk: a. meningkatkan kepedulian dalam perlindungan dan pengelolaan lingkungan hidup; b. meningkatkan kemandirian, keberdayaan masyarakat, dan kemitraan; c. menumbuh kembangkan kemampuan dan kepeloporan masyarakat; d. menumbuh-kembangkan ketanggapsegeraan masyarakat untuk melakukan pengawasan sosial; dan e. mengembangkan dan menjaga budaya dan kearifan local dalam rangka pelestarian fungsi lingkungan hidup.

Berdasarkan pasal tersebut, maka beberapa hal yang dapat dilakukan perempuan adalah untuk senantiasa mengembangkan semangat keibuan (spirit of mothering) dan etika lingkungan (environmental ethics) untuk lebih peduli terhadap lingkungan. Hal ini penting dilakukan karena perempuan adalah bagian dalam keluarga yang mempunyai peran penting sebagai menjadi pendidik sekaligus pelaku pertama untuk menjaga kualitas sedini serta seintens mungkin dalam keluarganya. Selain itu perempuan juga berperan penting untuk mendorong pengintegrasian perspektif perempuan dalam berbagai kebijakan terkait dengan pemanasan global dan perubahan iklim. Dengan demikian dapat disimpulkan bahwa perempuan dan lingkungan hidup merupakan sebuah harmonisasi interaksi yang indah antara kearifan kaum hawa dengan manfaat terbaik dari alam. Perempuan dalam perannya sebagai sebagai actor, leader dan decision makers dalam pelestarian lingkungan.

\section{Simpulan}

Dalam tataran teoritis maupun empiris, perempuan senantiasa memiliki kedekatan dan keterkaitan erat dengan lingkungan sekitarnya, akan tetapi keberadaanya sering diabaikan baik oleh struktur maupun kultur yang bias gender. Untuk meningkatkan peran perempuan dalam pelestarian alam secara nyata maka langkah awal yang perlu dilakukan adalah penjajangan kebutuhan. Penjajangan kebutuhan ini menghantarkan identifikasi alasan-alasan perlunya program pemberdayaan. Alasan-alasan perlunya pemberdayaan perempuan 
dalam pelestarian lingkungan di Desa Curug Muncar adalah adanya kerentanan yang bersifat multidimensional yakni ekologi, psikologi, ekonomi dan sosial. Oleh karena itu model pendekatan pemberdayaannya musti merujuk pada konsep pembangunan berkelanjutan, sebab model pendekatan ini bersifat multidispliner dengan mengkaitkan dimensi ekologi, ekonomi dan sosial secara bersamaan, hal ini akan relatif mudah diterima dan berhasil. Program pemberdayaan perempuan tersebut, maka meneguhkan bahwa geliat ecofeminisme pun dapat lahir di daerah pedesaaan. Meskipun levelnya masih sempit dan dampaknya masih perlu diperluas, tetapi semangat dan aksi mereka dalam pelesarian lingkungan hidup makin menempatkan peran perempuan adalah penting baik sebagai actor of social change,leader maupun decision makers dalam usaha pencarian solusi untuk menjaga dan melestarikan lingkungan hidup dan lingkungan sosial. 


\section{Daftar Pustaka}

Afandi, Agus dkk, 2013, Modul Participatory Action Reseacrh (PAR). IAIN Sunan Ampel Surabaya: Lembaga Pengabdian Masyarakat (LPM).

Amstrong, Susan J. dan Botzler, Richard G. (ed), 1993, Enviromental Ethics: Divergence and Convergence. New Yok, Mc Graw-Hill.

Hasbullah, J, 2006, Social Capital (Menuju Keunggulan Indonesia), MR-United Press, Jakarta.

Iskandar, Johan 2009, Ekologi Manusia Dan Pembangunan Berkelanjutan, Program Studi Magister Ilmu Lingkungan Universitas Padjajaran, Bandung.

Jahan, Momtaz, 2008, The Impact of Environmental Degradation On women In Bangladesh : An Overview,Journal Asian Affairs, Vol. 30, No. 2 : 5-15, AprilJune, CDRB publication.

Keraf, A. Soni, 2002, Etika Lingkungan, Penerbit Kompas, Jakarta.

Mangunjaya, Fachurudin M., 2006, Hidup Harmoni Dengan Alam, Esai-Esai Pembangunan Lingkungan Konservassi dan Keanekaragaman Hayati Indonesia, Yayasan Obor Indonesia, Jakarta.

Meidina, lsa, 2012, Gerakan Sabuk Hijau, Marjin Kiri, Jakarta.

Miles, Mattew B. dan Huberman, A Michael, 1992, An Expanded Soucers Book, Qualitive Data Analysis, Sage Publications.

Mirza, M. Monirul Qader, 2003, 'Climate Change and Extreme Weather Events: Can Developing Countries Adapt?', Journal Climate Policy 3.

Mulyadi, Muhammad dkk, 2015, Pembangunan Berkelanjutan : Dimensi Sosial, Ekonomi dan Lingkungan, Pusat Pengkajian, Pengolahan Data dan Informasi (P3DI) Sekretariat Jenderal DPR RI bekerjasama dengan Azza Grafika, Yogyakarta.

Murtakhamah, Titin, 2013, 'Pentingnya Pengarusutamaan Gender Dalam Program Pengurangan Risiko Bencana Welfare' dalam Jurnal Ilmu Kesejahteraan Sosial, Vol.2, No.1, Juni 2013.

Najmun, S., 2008, Ecofeminism: Global and Bangladesh Context. Asian Studies, Journal of the Department of Government and Politics, J.U.; 27, Dhaka.

Nasrin, Farzana, 2012, Women, Environment and Environmental Advocacy : Challenges For Bangladesh, Asian Jurnal of Social Sciences and Humanities, 2012, Vol. 1. No. 3. August 2012 http://www.ajssh.leenaluna.co.jp/AJSSHPDFs/Vol.1(3)/AJSSH2012(1.3-16)

Norlha, 2015, Impact of natural disasters on girls and women, Literature compilation of key facts and recommendations for relief practitioners with 
regard to the earthquakes in Nepal, Norlha Aide aux populations himalayennes, hlm.2 June 2015http://norlha.org/ wpcontent/uploads/2015/04/Impact_of_natural_disaster_on_girls_and_ women_Norlha_June_2015.

Organisation for Economic Co-operation and Development (OECD), 2008, Gender and Sustainable Development : Maximising The Economic, Social and Environment Role of Women, https://www.oecd.org/ social/40881538.pdf.

OSAGI, 2001, "Fact sheet on Important Concepts underlying Gender Mainstreaming", http:/ / www.un.org/womenwatch/osagi/pdf/factsheet2.pdf

Raana, Haider, 1994. 'Women, Poverty and the Environment', in A. Atiq Rahman et al. (eds.), Environment and Development in Bangladesh, 2,. Dhaka: University Press Ltd.

Radar Pekalongan, 2015, Longsor, Dua Desa Terisolir, 20 Desember 2016. http:/ / radarpekalongan.com/62387/longsor-dua-desa-terisolir/

Rismawati, Shinta Dewi, 2011, Rekonstruksi Kelembagaan dan Pranata Hukum Di Bidang Ketenagalisrikan Berbasis Modal Sosial (Studi tentang Penguatan Pengelolaan Mikrohidro Curug Muncar Pekalongan, Disertasi, UNDIP, Semarang.

Salman, Aneel, 2007, Ecofeminist Movements : from the North to the South, CThe Pakistan Development Review 46 : 4 Part II (Winter 2007), pp.853-864. http:/ / citeseerx.ist.psu.edu /viewdoc/download?doi=10.1.1.663.309\&rep $=$ rep $1 \&$ type $=$ pdf, hlm. 859

Sessions, George, 1995, Deep Ecology for the 21 ${ }^{\text {st }}$ Century : Reading on The Philosophy and Practice of the New Enviromentalism, Shambhala, Boston.

Shiva,Vandana dan Meis, Maria, 2005, Ecofeminism : Prespektif Gerakan Perempuan dan Lingkungan, Penerbit IRE Press, Yogyakarta.

Suharto, Edi, 2005, Pembangunan dan Pemberdayaan Masyarakat, Pustaka Pelajar, Yogyakarta.

Syafaat, Rahmat, 2006, Advokasi dan Pilihan Penyelesaian Sengketa, Latar Belakang, KOnsep dan Implementasi, Agritek YPN Malang.

Tim LPTP Solo, 2010, 'Agenda Perempua Dalam Gerakan Petani' Dalam Jurnal Muzawah, Vol. 2, No. 1, Juli 2010.

Widjanarko, Mochamad dan Indaryani, Mamik, 2015, 'Perempuan Merawat Komunitas Ketika Bencana : Kajian Ekologi Di Desa Rahtawu Kudus Pegunungan Muria' dalam Jurnal Perempuan Vol. 20 No. 3 Agustus 2015. 
Geliat Ecofeminisme Pedesaan ...

Yadav, Naresh, tt,WomenE Environment Sustainability, http:// www.vigyanprasar.gov.in/ Radioserials/12women_\&_ environment.pdf Naresh Yadav, Women \& Environment Sustainability.

Yasmeen, Ahmed, 1995, "Environmental Degradation and Natural Disasters: Who are the worst victims?" in Shamim, Ishart and Salahuddin, Khaleda (eds.),Towards Beijing and Beyond: Women Shaping Policies in Areas of Concern, Dhaka : Centre for Women and Children studies.

Yuliana, Sri, 2015, "Perempuan Merawat Air, Tanah dan Keluarga : Kajian Kedaulatan Pangan di Air Sugihan Ogan Komering Ilir, Sumatera Selatan,' Dalam Jurnal Perempuan Vol. 20 No 3 Agustus 2015. 